\title{
Recycling in the Canadian pulp and paper industry ${ }^{1}$
}

\author{
by Brian McClay ${ }^{2}$
}

\section{Introduction}

In this article I will present a Canadian perspective on recycling in the pulp and paper industry. It is readily apparent that whatever is happening to paper recycling today and in the near future will have a material impact on Canadian paper producers.

First, a few thoughts of my own on what the renaissance of recycling means for the paper industry in broad terms. It certainly means much more than just increased demand for waste paper and changes in the level of comparative advantage between individual mills and regions. It is already causing a fundamental shift in the way we conduct almost every aspect of our business. Paper recycling used to be driven primarily by raw material costs. It is now consumer driven; a shift of revolutionary proportion. It has alreaedy forced the industry to build new communications networks and business alliances. It has motivated papermakers and their spokespersons to reach out and tell the "industry story", to municipal officials, state and federal legislators, environmental groups and ordinary citizens. Papermakers are now working with waste haulers, ink and glue manufacturers and consumer product companies to expand recycling options and to advance recycling technology. Inter-industry partnerships have been established to collect and transport waste paper. Fundamental research is accelerating, not just on recycling but also on the collateral issues of composting and the wasteto-energy option related to sludge disposal. Life cycle analysis is being developed and must be developed for all of our products. Producers are undertaking mill trials and pilot projects with materials that would not have been allowed near paper mills a few years ago. In short there has seldom if ever been so much widespread "hard thinking" and interest in a paper industry issue. And although the recycling revolution will surely create winners and losers, over the medium term, the industry should be better off because its imagination and creativity have been stimulated, information is now flowing freely up and down the production/distribution chain across industries, and has been challenged to achieve a fairly well defined goal: to maximize the economically efficient diversion of discarded paper and paperboard from landfills.

In the meantime, however, new demands for increased recycling will cause problems for papermakers generally and for much of the Canadian industry in particular. Fundamentally, increasing recycling in Canada is and will continue to be a difficult task because of the industry's structure and its current shortage of available capital.

\footnotetext{
${ }^{1}$ This article has been adapted for publication in The Forestry Chronicle from a presentation made by Brian McClay to Wastepaper II: Markets \& Technologies in the ' 90 s, a conference sponsored by Pulp and Paper, Pulp and Paper Week, Chicago. May 21-23, 1991.

${ }^{2}$ Canadian Pulp and Paper Association, Montreal, PQ.

${ }^{3}$ Waste Paper Utilization Rate: waste paper consumed as a percent of the total fibre consumed in paper and paperboard products.
}

Table 1. Export dependence, Canadian and U.S. pulp and paper industry

\begin{tabular}{lcc}
\hline & Canada & U.S.A. \\
\hline Domestic & $22 \%$ & $93 \%$ \\
Exports & $78 \%$ & $7 \%$ \\
\hline
\end{tabular}

\section{Export Dependence}

Canada is the world's second largest pulp, paper and paperboard producer. It's about one-third the size of the U.S. industry. Today, about 11 percent of the fibre it consumes is waste paper, compared to 21 percent in the U.S. But what's critically important here for existing and future recycling rates is not the industry's size but its export dependence (Table 1) and grade structure.

The Canadian industry is skewed to the international commodity end of the business. We export around 78 percent of our output compared to just 7 percent for the U.S. industry. This obviously has major implications for domestic waste paper supply. Canadian consumption of paper and paperboard, including about 1 million tonnes of imports, equates to only one-third of our production. Doing the arithmetic and making the optimistic assumption of a 50 percent recovery rate, our domestic waste paper supply could support an industry waste paper utilization rate ${ }^{3}$ of only 15 percent. Therefore, imports of waste paper will play an increasingly important role as Canada's recycling capacity rises, and we will have to compete for this fibre on the world market.

\section{Grade Structure}

The grade structure of the Canadian and United States industries also helps to reveal why recycling has so far made only a modest contribution to papermaking in Canada in volume terms (Table 2). Canadian capacity to produce market pulp and newsprint accounts for almost 70 percent of the Canadian industry total, compared to only 17 percent in the United States. These products are heavily export dependent and have had only a modest experience with recycling. At the other end of the product spectrum is packaging paper and board; typically waste paper dependent grades produced for the domestic market. Supply of these grades account for only 13 percent of Canadian industry capacity compared to around 51 percent in the United States.

What about the future? Canadian producers, especially in the newsprint sector, have already moved a long way to meeting the recycling challenge. They have invested or committed to invest around $\$ 1.5$ billion to increase their recycling capacity.

\section{Waste Paper Consumption Forecast}

Waste paper consumption by Canadian paper and paperboard mills will rise 75 percent between 1990 and 1993 compared to around 8 percent in the United States (Table 3). 
Table 2. Annual capacity, Canadian and U.S. pulp and paper industry

\begin{tabular}{lrrrrr}
\hline & \multicolumn{2}{c}{ Canada } & & \multicolumn{2}{c}{ U.S.A. } \\
\cline { 2 - 3 } \cline { 5 - 6 } & 000's tonnes & \% & & 000's tonnes & \% \\
\hline Market pulp & 9,000 & 33 & & 8,470 & 10 \\
Newsprint & 10,000 & 38 & & 6,175 & 7 \\
Printing and writing & 4,250 & 16 & & 22,130 & 26 \\
Tissue & 600 & 2 & & 5,415 & 8 \\
Packaging paper and board & 3,830 & 13 & & 43,385 & 51 \\
Total & 27,480 & 100 & & 85,575 & 100 \\
\hline
\end{tabular}

Table 3. Recyclable paper consumption, Canada and U.S., 1990/1993

\begin{tabular}{|c|c|c|c|c|c|c|}
\hline & \multicolumn{3}{|c|}{ Canada } & \multicolumn{3}{|c|}{ U.S.A. } \\
\hline & 1990 & 1993 & \% Ch. & 1990 & 1993 & \% Ch. \\
\hline Container grades & 940 & 1,000 & 6 & 10,731 & 11,593 & 8 \\
\hline Pulp subs, others & 420 & 550 & 31 & 4,634 & 5,053 & 9 \\
\hline News grades & 230 & 1,365 & 493 & 4,098 & 4,457 & 9 \\
\hline Mixed papers & 110 & 120 & 9 & 2,583 & 2,723 & 5 \\
\hline \multirow[t]{2}{*}{ Box cuttings } & 90 & 95 & 6 & $\mathrm{AE}$ & $\mathrm{AE}$ & - \\
\hline & 1,790 & 3,130 & 75 & 22,044 & 23,826 & 8 \\
\hline
\end{tabular}

Most of the Canadian increase will come from the installation of deinking plants to produce newsprint. The demand for "'news grades" of waste paper, predominantly old newspapers (ONP), will increase by nearly 500 percent over the next three years. Since Canada consumes only 1.1 million tonnes of newsprint and waste collection systems are not well established, with a few important exceptions, a large share of the waste paper required to satisfy this new demand, perhaps 800000 tonnes, will be imported from the United States. In 1990, imports from the U.S. accounted for about 30 percent of Canada's waste paper supply; by 1993 their share will likely reach over 50 percent.

Over the 1990-1993 period, Canada's waste paper utilization rate will increase from 11 percent to 18 percent, while in the U.S. it will rise from 21 percent to 23 percent. Moreover, waste paper consumed by Canadian paper and paperboard mills as a percent of Canadian paper and paperboard consumption will rise from 31 percent in 1990 to 52 percent in 1993.

\section{Recycled-content Newsprint}

So far most of the pressure to increase recycling has been focused on the newsprint sector. There are eight U.S. states which have passed laws mandating that newspaper publishers use certain volumes of recycled-content newsprint. In another nine states, publishers have signed voluntary agreements with legislators or governors to the same effect. Even though most people believe that there is a 40 percent minimum-content standard defining recycled-content newsprint $(\mathrm{RCN})$ only 3 of 17 states have stipulated such a requirement (i.e.) California, Arizona and Florida; all the others use a blended or aggregate target approach. But what drives change is strong pressure from the market and demands for increased recycling from newsprint costomers are coming in loud and clear. Many publishers have added recycled-content supply stipulations to their newsprint contracts and this has quickly focused the attention and driven the investment decisions of newsprint producers in both Canada and the United States.

\section{Canada}

Today in Canada there are only two mills producing recycled-content newsprint with deinked waste paper. Quebec and Ontario Paper Co. in Thorold, Ontario and Atlantic Newsprint Co. near Toronto. However, by the end of next year Canada will have at least 13 newsprint mills able to supply recycled-content paper. All of them will install floatation deinking systems which means that the waste paper furnish will average around 70 percent ONP and 30 percent Old Magazines (OMG). This new capacity will increase Canada's demand for "news grade" waste paper by almost 500 percent between 1990 and 1993; from around 230,000 tonnes to 1.37 million tonnes, and as I mentioned earlier, as much as 800,000 tonnes will be sourced in the U.S.

In 1990 less than 2 percent of the fibre used to produce Canadian newsprint was waste paper; its share will rise to 13 percent in 1993 , and to perhaps 25 percent by the turn of the century.

This is in a way a good news/bad news story. The industry's increased deinking of waste paper will certainly create much needed demand for the growing volumes of waste paper being diverted from landfills, but it will also generate huge quantities of deinked sludge which will have to be disposed in an economically sound and environmentally sensitive manner. For example, if about one-half tonne of wet sludge is created for every tonne of waste paper deinked, in 1993 Canadian newsprint mills will generate an additional 700,000 tonnes of this waste material. The idea of landfilling it defeats one of the primary reasons for recycling in the first place, so the Canadian industry, through the Pulp and Paper Research Institute of Canada (PAPRICAN), is working to optimize the combustion and composting potential of this material.

\section{United States}

The U.S. newsprint situation is similar. Today there are eight existing mills using waste paper as furnish; by 1993 the list will include seven more mills which are installing deinking plants of their own. In 1990 waste paper accounted for 27 percent of the fibre used to produce U.S. newsprint; that will rise to 38 percent by 1993 . The aggregate North American waste paper utilization rate for newsprint was 14 percent in 1990 and it is projected to increase to 25 percent by 1993 .

\section{Paper Quality}

On the product quality side, although one shouldn't generalize, it is becoming increasingly evident that recycledcontent newsprint is acceptable for most end-uses. Its runnability is similar to that of virgin-fibre paper and its printability characteristics are improving and will continue to improve because the competitive nature of the paper business ensures that producers will strive to respond to customers quality requirements.

\section{Other Publication Grades}

The market pressure to increase the recycled-content of other publication papers has so far been fairly narrowly focused and less urgent than that for newsprint. 


\section{Mechanical Paper Grades}

For mechanical grades (groundwood papers) the pressure has targeted "directory" paper primarily because directories are produced in significant volume, they are bulky, highly visible and have a fixed useful life. On the legislative side, two states, California and Connecticut, have passed laws mandating that printers use a certain volume of recycledcontent paper. (The Connecticut Law becomes effective in 1995 and is targeted at directories only).

In North America today only one mill produces uncoated mechanical grades using waste paper, Manistique Paper in Michigan. Two others produce coated mechanical grades in small quantities; Repap Enterprises and Niagara of Wisconsin Paper Corp.

Over the next two years three other mills will install deinking units at newsprint mills which also produce directory paper. Daishowa Forest in Port Angeles, Washington and Quebec City, Quebec and Champion International Corp. at Sheldon, Texas. It is very likely that other mills will develop new grades using purchased deinked pulp when the capacity for that product increases.

\section{Wood-free Papers}

There are approximately thirty-six mills in operation in North America supplying generally small quantities of a wide range of recycled-content uncoated wood-free papers; many of them have been doing so for years. A number of them have on-site deinking facilities but many depend on purchased deinked pulp, especially those which have very recently begun to produce recycled-content paper. They tend to be small-to-medium specialty paper mills. By going through a number of the capacity projects surveys, I found that very few deinking plants are planned to be installed at these or similar facilities. Increased capacity to produce these papers will depend for the most part on the increasing supply of market deinked pulp.

\section{Market Deinked Pulp}

There are five market deinked pulp mills in operation in North America today with a combined annual capacity of only 200,000 tonnes. However, another five mills with a combined capacity of around 650,000 tonnes will come on stream by 1993 . At least 20 per cent of that capacity will be targeted at newsprint mills. So it's likely there will be considerable growth in the production of recycled-content publication paper, other than newsprint, over the next few years.

\section{Summary}

In conclusion, I think it's fair to say that the paper industry has responded very quickly to the market's growing demand for more recycling. It now will continue to respond by optimizing the deinking process and improving the quality and variety of its recycled paper products because that's what consumers want, and the paper industry is increasingly a consumer driven business. 